\title{
O vampiro do campus
}

\author{
Conto de Flávio R. Kothe
}

Por eu estar fazendo em 1972 o doutorado em química, morava no Conjunto Residencial da Universidade, partilhando um apartamento de três quartos com dois colegas: um era botânico, comparava plantas da costa leste brasileira com similares da costa oeste africana, para determinar onde teria havido a separação entre os continentes e assim ver onde se deveria buscar petróleo (o que garantia ao colega o financiamento das viagens para Angola); o outro era um biólogo, estudava a acidez do trato digestivo do urubu, para saber por que não morriam ao ingerir carnes putrefatas que seriam fatais aos humanos. O biólogo tinha de enfiar tubos de coleta e medição na entrada e na saída dos negrinhos: eu brincava com ele, dizendo que seria doutor em grau de acidez do cu do urubu, ameaçando tornar gays todos os seus assessores emplumados. Quando via o botânico gargalhando, ele ria meio sem jeito.

Em geral eu estava sozinho no apartamento, pois os outros tinham de viajar para fazer pesquisas de campo. Como eu já estava quase terminando a tese, recebi, naqueles tempos de carência de cérebros fomatados, uma sondagem para assumir, assim que concluísse, um posto de professor e um laboratório numa universidade do Nordeste: como ficava à beira-mar, estava inclinado a ire estou nela até hoje. Acabei até casando com uma namorada da adolescência. Isso não me impediu de, enquanto ainda estava no Conjunto, trocar alguns fluidos corporais com uma estudante belga que lá morava.

Foi assim que conheci sua colega de apartamento, Elisa, uma luterana de Santa Catarina, que fazia doutorado em metafísica e mitologia comparada, como se isso fizesse qualquer diferença no mundo prático. Eu brincava dizendo que era melhor estudar logo teologia ou astrofísica, em vez de tentar saber tudo sobre o nada. Ela tentou até me convencer de que as teorias em que se metiam tinham consequências práticas, não só pessoais, mas nacionais. Ficava brava com as minhas brincadeiras.
Era capaz de gastar uma hora sobre os vários sentidos de uma palavra, não parava de falar. Queria provar que o "jeitinho brasileiro" e a "malandragem carioca" tinham origem teológica: argumentava que o católico queria se dar bem, trocando algumas missas e moedas pela vida eterna, um investimento pequeno para um lucro eterno, que aplicar isso em tirar vantagens no dia a dia era café pequeno. Eu dizia que nessa aposta se pagava com a vida para ver as cartas postas na mesa, e ria. Ela ficava fula, citava uma tal de "doutrina da graça” do século XVIII, e eu achava mais graça ainda.

Eu era indiferente ao problema dela, pois até hoje ninguém voltou da morte para dizer se há céu $e$ inferno, não há prova física deles. Eu não queria me deixar enganar pelo que considerava enganações. Eu me considerava um homem de ciência, não de crença. Eu me norteava por hipóteses, leis químicas e dúvidas, não por dogmas. Estava convencido de que a ciência um dia dominaria o universo.

Para Elisa, todo aquele que acreditava obter a bemaventurança eterna em troca de missas e genuflexões era, porém, um oportunista, queria se dar bem com um jeitinho! Investindo pouco, obter um lucro infinito. Num mundo injusto, não seria possível ser bem justo. Como quer que se fizesse, errado se faria. O problema, para ela, é que o jeitinho definia o homem brasileiro.

Isso não servia ao orientador dela nem ao grupo de professores e alunos em torno dele. Eles eram defensores entusiastas dos caipiras e, com isso, achavam que defendiam o nacional e o popular, como se com isso se fizesse melhor ciência, arte e filosofia! Ouvi dizer que ela passou a ser hostilizada por esse poderoso grupo, que detinha bolsas e vagas de emprego nas universidades do Estado. Eu, que nem era da área, conseguia entender a indignação de Elisa, a minha Chanticler, mas dizia que ela iria se dar mal se insistisse em suas teses fora dos eixos do senso comum. 
Nós, no laboratório, queríamos saber se as nossas teorias e hipóteses estavam corretas, se elas cabiam nos parâmetros consagrados nos países mais avançados. Num país que recém começava ciência, ainda não estávamos propondo mudar parâmetros mundiais. Obedecíamos ao que vinha de fora. Na área de humanas, no entanto, eles, donos de cargos e prestígio, tanto mais presunçosos e arrogantes quanto mais ignorantes, achavam ser verdade o que eles diziam que fosse: como tinham o poder, decidiam sobre o que poderia aparecer e o que não poderia, quem teria emprego e quem não teria. Eu não competia com eles. Queria um laboratório, praia e sossego.

Elisa teimava, no entanto. Quanto maiores as resistências, maior seu fervor de convencer e converter. Era uma cristã radical, dessas que acham que precisam levar todos à salvação. Parecia inteligente, mas era inocente, não sabia por onde andava. Até que alguma coisa aconteceu, não sei bem o quê. Ela deve ter sofrido alguma rejeição explícita do grupo ou do próprio orientador: um chega para lá, não coisa qualquer. Talvez tenham lhe cortado a bolsa, talvez a família não tivesse condições de sustentar seus estudos.

Vendo que não podia argumentar com os outros nem comigo, foi se retraindo cada vez mais. Parecia uma monja luterana sem convento. Até que começou a especular sobre vampiros que dizia voarem pelo campus: eu achava que ela estava ficando doida, mais ainda quando dizia que eles se disfarçavam de dia como guardiões dos valores acadêmicos. Eu só ria desses absurdos dela.

No laboratório, eu misturava, aquecia, pesava, media: não via fantasmas voando, nem mesmo nos vapores e miasmas que saíam dos meus frascos. Eu era químico, não alquimista. Não queria perder tempo com especulações que a ciência havia superado. Não tinha cabeça para filosofices baratas.
Por que estou a escrever isso agora, tantos anos depois? Há poucas semanas, o orientador dela morreu, a fotografia dele apareceu nos jornais: parecia o vampiro de Düsseldorf! Olhos esbugalhados, nariz adunco, quase careca, magrelo e curvo. Isso por si não teria a menor importância, ninguém é culpado da feiura na velhice nem de parecer com alguém.

O que me perturbou - e isso me faz ainda vacilar, eu quase não consigo continuar o relato - é algo que lá aconteceu no fatídico ano de 1973 (que o capeta o tenha!). Eu, que tenho tantas fórmulas químicas na cabeça, não sei se a memória me trai ou se o tempo me faz imaginar coisas que nem existiram. Não posso confiar em mim. No entanto, relato.

Como eu estivesse sozinho no apartamento, a minha canária belga tinha passado a noite cantando comigo. Pela manhã cedo, voltou ao seu quarto. Pouco depois reapareceu, pálida e trêmula, na minha porta. Misturando francês com português e as duas mãos me puxando, me fez ir até o apartamento dela. Fui lá esperando o pior, e o pior estava lá!

O corpo de Elisa se encontrava inerme e exangue, ela ainda sentada na cadeira, com o rosto entre os braços deitados sobre a tampa da escrivaninha posta diante da janela. Não sei se lembro bem, ou se o tempo me fez ver o que não havia. Dois furos no pescoço da morta me perseguem a memória desde então, mas eu não queria acreditar no que via. A janela estava aberta, a brisa fria da manhãzinha entrava por ela. O corpo gélido, o rosto branco, os braços sobre um texto: uma página meio escrita, como se ela acreditasse que escrever era necessário para que o sol surgisse pela manhã. Por isso eu às vezes a chamava de Chanticler.

Puxei o texto, para ver se era de despedida, se continha o segredo da morte. Lá estava ela a discorrer sobre a doutrina de Jansenius, um teólogo do século XVII, como se o rigor moral da doutrina da graça pudesse 
se comparar à malemolência, a driblar o rigor da lei para obter vantagens pessoais. Ela já havia me pregado isso: se o saber divino seria sempre diferente do humano, não haveria como negociar com Deus para exigir salvação! Quem tem todo o poder pode tudo, não precisa nem saber muito. Eu até entendia que isso seria reduzir a Igreja como instituição a um engodo, o que os jesuítas haviam percebido bem e acabado com a casta dos jansenistas e toda a escola de Port Royal.

Elisa havia escrito até à morte. Era como se quisesse, com palavras, enfrentar o silêncio que a todos rodeia. Era como se, escrevendo, pudesse dizer o que the impediam de falar. O silêncio que o grupo the impunha, ela queria romper com riscos no papel. As palavras vinham de onde lhe obrigavam a calar. Era a ilha que construía na sua solidão. Todas as palavras que ela escreveu se perderam, ninguém as quis preservar.

Para mim, nordestino da gema, era estranho que o orientador dela, que provinha da oligarquia do café com leite, se dissesse nacionalista e engajado, autêntico e nobre, por se identificar com o que ele chamava de "povo caipira" e de "causas populares". A mim parecia que ele era daqueles que gostavam tanto do "povo" que preferiam que sua miséria continuasse a ser como sempre já havia sido. Eu não acreditava que esse povo simples fosse fazer ciência ou arte, mesmo que haja tantos artistas metidos a "populares". Eu não via nobreza no sotaque caipira, como também não achava vantagem nenhuma o sotaque da minha região natal. Não valia nada por si!

O que fazer, tendo um cadáver diante de nós? Combinei com a minha belga que o melhor para nós seria dizermos a verdade: que tínhamos passado a noite juntos no meu quarto, não tendo ouvido nem visto nada do que acontecera com Elisa. Dizer a verdade era um modo de mentir melhor, de não entrar nas questões que poderiam estar por trás daquela morte, não nos metermos no imbróglio. Melhor enfrentar as possíveis penas de termos ficado juntos do que ficarmos suspeitos de assassinato. No máximo seríamos expulsos do alojamento. Assim, fui avisar na portaria o que havia acontecido, para que ambulância e polícia fizessem o que lhes cabia.

Assim que família de Elisa foi avisada, os pais vieram, para levar o corpo para o cemitério luterano de sua cidade natal. Teve sorte em não ser considerada suicida, pois se não nem última morada teria. Não ouvimos mais falar dela. A minha canarinha belga deume depois amostras de boa gratidão por eu ter lhe dado um álibi em terra estranha. Nosso amor tinha, porém, prazo de validade marcado. No fim do ano, ela voltou para a Bélgica, eu fui cuidar da vida na beira do mar.

Pelo que eu soube, o orientador passou a tomar mais cuidado na seleção dos doutorandos e só admitia ainda quem comprovadamente rezasse pela cartilha dele. A quem pensasse que ele era desonesto, todo o grupo ao redor suprimia as suspeitas com elogios sistemáticos a tudo o que ele dissesse ou escrevesse. Eu não acreditava, porém, que ele fosse a pitonisa ressurrecta, pois nem na pitonisa acreditava.

Como eu não tinha nada a ver com as humanidades, lavei as mãos como lavava o material do laboratório. Com cuidado. Terminei minha pesquisa, redigi a tese, fiz a defesa e fui embora, me mandei para a minha terra natal, no emprego que me haviam oferecido. Cumpriram a promessa de me dar um laboratório equipado, onde eu pudesse pensar por conta própria.

Claro, fiz a bobagem de acabar casando com a namorada que ficara de plantão me esperando, tratando de esquecer a canarinha belga. Mas não consegui. Durante a noite, na escuridão em que os vampiros revoam, eu me vi levado a estranhas encruzilhadas. Aprendi a cultuar Exu, no início sem charutos nem pingas, mas aos poucos me acostumando às usanças dele, até que minha mulher decidiu se separar de mim, no que tinha toda razão. Mas isso já é outra história. 
104 Revista Estética e Semiótica | Volume 8 | Número 1 